\title{
Radiological foresight: a rare case of breast cancer metastases to the extraocular muscles
}

\author{
Nyla Alam Khan, John Morlese, Arshad Khan
}

Department of Radiology, Leicester Royal Infirmary, Leicester, UK

\section{Correspondence to} Dr Nyla Alam Khan, nyla.a.khan@gmail.com

Accepted 26 June 2015

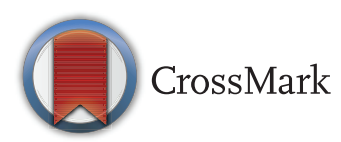

\footnotetext{
To cite: Khan NA, Morlese J, Khan A. BMJ Case Rep Published online: [please include Day Month Year] doi:10.1136/bcr-2015211264
}

\section{DESCRIPTION}

A woman with a 1-year history of diplopia presented to the Ophthalmology Clinic in June 2014. She had a known history of infiltrating ductal carcinoma of the breast with metastasis to the bone and had undergone chemotherapy for this. On the day of her consultation, her visual acuity was 6/9 bilaterally and she was experiencing diplopia in extreme up and down gazes. She was referred for an MRI of the head and orbits, which revealed multiple metastatic deposits to the multiple extraocular muscles bilaterally (figures 1 and 2) as well as within the brain.

Although rare, there are accounts of numerous malignancies with metastasis to the orbits, including breast, lung, genitourinary and gastrointestinal tumours. ${ }^{1}$ Of these, breast tumours have been reported as the most common malignancy to do so. ${ }^{2}$ However, bilateral metastasis to more than two extraocular muscles of this tumour, such as in this case, has been acknowledged as being very unusual. $^{3}$

Patients with metastasis to the extraocular muscles usually present with symptoms of reduced vision, diplopia and pain in the region. Additionally, they may experience proptosis and ptosis.

The diagnosis can only be confirmed histologically. In this case, the patient underwent a muscle biopsy from the left extraocular muscle, which

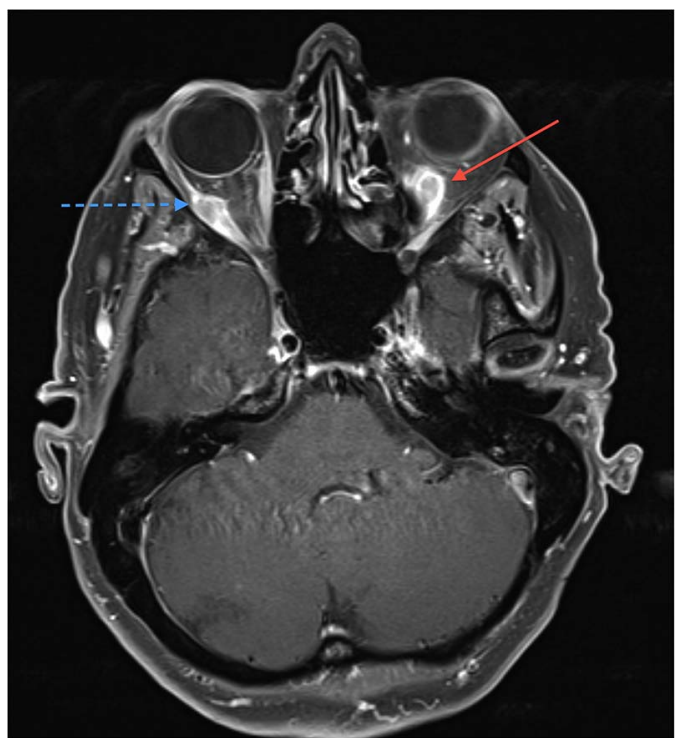

Figure 1 MRI T1 fatsat post contrast axial slice: demonstrating breast cancer metastatic lesions in the left inferior rectus (red arrow) and right lateral rectus (blue dashed arrow).

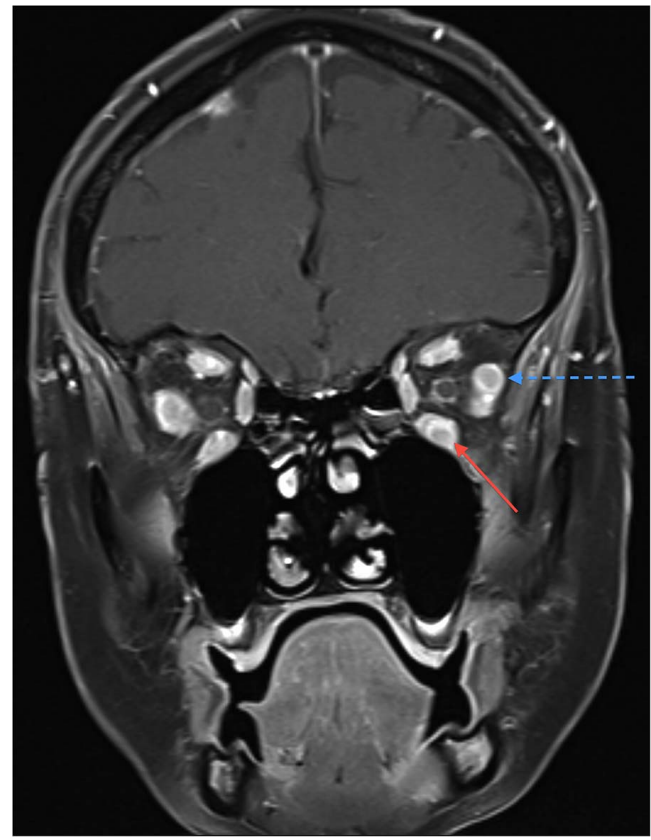

Figure 2 MRI T1 fatsat post contrast coronal slice: demonstrating breast cancer metastatic lesions in the left lateral rectus (blue dashed arrow) and left inferior rectus muscle (red arrow).

confirmed the diagnosis of breast cancer metastasis. She was treated with whole brain radiotherapy and a follow-up MRI demonstrated she had had a partial response to this. She currently continues management under oncology.

\section{Learning points}

- Numerous malignancies are known to metastasise to the orbits, with malignancy of the breast remaining the most common to do so.

- Bilateral metastasis to more than two extraocular muscles is a very rare finding.

- Clinical suspicion of metastatic spread to the orbits should remain high in patients with a known history of carcinoma who present with relevant symptoms.

Acknowledgements Dr Nagini Sarvanathan (consultant ophthalmologist) and Dr lon Boiangiu (consultant oncologist).

Competing interests None declared.

Patient consent Obtained. 
Provenance and peer review Not commissioned; externally peer reviewed.

\section{REFERENCES}

1 Weiss R, Grisold W, Jellinger $K$, et al. Metastasis of solid tumours in extraocular muscles. Acta Neuropathol 1984;65:168-71.
2 Spitzer SG, Bersani TA, Mejico LJ. Multiple bilateral extraocular muscle metastases as the initial manifestation of breast cancer. J Neuroophthalmol 2005;25:37-9.

3 Bedford PD, Daniel PM. Discrete carcinomatous metastases in the extrinsic ocular muscles. A case of carcinoma of the breast with exophthalmic ophthalmoplegia. Am J Ophthalmol 1960;49:723-6.

Copyright 2015 BMJ Publishing Group. All rights reserved. For permission to reuse any of this content visit http://group.bmj.com/group/rights-licensing/permissions.

BMJ Case Report Fellows may re-use this article for personal use and teaching without any further permission.

Become a Fellow of BMJ Case Reports today and you can:

- Submit as many cases as you like

- Enjoy fast sympathetic peer review and rapid publication of accepted articles

- Access all the published articles

- Re-use any of the published material for personal use and teaching without further permission

For information on Institutional Fellowships contact consortiasales@bmjgroup.com

Visit casereports.bmj.com for more articles like this and to become a Fellow 